\title{
ANALISIS KETERAMPILAN MENULIS TEKS ULASAN DENGAN METODE QUANTUM LEARNING BERBANTUKAN GOOGLE CLASSROOM
}

\author{
Yustiyawati*1, Cahyo Hasanudin ${ }^{2}$, Ahmad Kholiqul Amin ${ }^{3}$ \\ Program Studi Pendidikan Bahasa dan Sastra Indonesia, Fakultas Pendidikan Bahasa dan Seni, IKIP \\ PGRI Bojonegoro \\ e-mail: *1yustiya13@gmail.com, ${ }^{2}$ cha.sanu.88@gmail.com, ${ }^{3}$ choliqamin@gmail.com
}

\begin{abstract}
ABSTRAK
Teks ulasan merupakan salah satu teks yang memuat tentang penilaian sebuah karya. Penelitian ini bertujuan untuk mengetahui bentuk struktur teks ulasan (evaluasi, orientasi, tafsiran dan rangkuman) yang telah ditulis siswa. Penelitian ini merupakan penelitan deskriptif kualitatif dengan pendekatan study kasus. Subjek penelitian ini terdiri dari 16 siswa. Teknik pengumpulan data dengan tes, observasi, wawancara dan dokumentasi. Hasil penelitian menunjukkan bahwa siswa kelas VIII SMP Katolik St. Louis Cерu dapat menulis teks ulasan pada bagain 1) orientasi dikategorikan baik, 2) tafsiran dikategorikan baik, 3) evaluasi dikategorikan baik, dan 4) rangkuman dikategorikan baik. Simpulan penelitian ini adalah pengguna metode quantum learning berbantukan google classroom dapat membuat siswa menulis teks ulasan lebih baik.
\end{abstract}

Kata kunci: teks ulasan, quantum learning, google classroom.

\begin{abstract}
Review text is one of text that contains the assesment of an artworks. The purpose of this research is to identify the text structure of review text (interpretation, orientation, evaluation and summary) which has been written by students. This research is a qualitative descriptive research with case study approach. Subject of this research consists of 16 students. Collecting data technique which is used are observation, test, interview and documentation.The result of research shows that the eighth grade students of SMP Katolik St. Louis Cepu are able to write review text in part of 1) orientation categorized good, 2)interpretation categorized good, 3) evaluation categorized good, 4) summary categorized good. The conclusion of this research is the usage of quantum learning method with google classroom is able to make students to write review text better.
\end{abstract}

Keywords: review text, quantum learning, google classroom.

\section{PENDAHULUAN}

Mata pelajaran bahasa Indonesia ditemui pada semua jenjang pendidikan. Mata pelajaran ini adalah salah satu mapel yang dapat dipelajari di dalam kehidupan sehari-hari, namun kadang dianggap sulit oleh siswa [1]. Pembelajaran bahasa Indonesia mempunyai cakupan yang sangat luas sehingga sangat penting untuk dipelajari agar siswa dapat lebih mendalami dan dapat berbahasa Indonesia dengan baik [2]. Peningkatkan kemampuan komunikasi siswa dalam bentuk lisan maupun tulisan merupakan tujuan dari pembelajaran bahasa Indonesia [3]. Ada beberapa keterampilan dalam pembelajaran bahasa Indonesia diantaranya keterampilan menyimak, keterampilan berbicara, keterampilan membaca dan yang terakhir adalah keterampilan menulis. Beberapa keterampilan berbahasa tersebut saling berkaitan dalam sebuah pembelajaran dan memiliki fokusnya masing-masing. Misalnya dalam hal menulis, siswa difokuskan pada keterampilan menulis.

Keterampilan menulis adalah salah satu keterampilan yang juga harus dapat siswa kuasai. Sebab tidak dapat kita pungkiri bahwa menulis selalu ada dalam keseharian kita. Keterampilan menulis adalah salah satu cara berbicara tidak langsung untuk menyampaikan suatu gagasan atau pikiran dalam bentuk tulisan [4]. Menulis adalah salah satu keterampilan berbahasa yang membutuhkan keaktifan dan kreativitas otak dalam menyampaikan pikiran [5]. Keterampilan 
Jurnal SEMANTIKA, Volume 03, No. 01, Agustus 2021, pp. 1-9

menulis sangat penting bagi siswa dalam merasakan hubungan, daya tanggap dan membantu siswa dalam memecahkan masalah [6].

Seseorang dikatakan berhasil dalam keterampilan menulis apabila orang tersebut dapat mengungkapkan pikirannya dalam bentuk tulisan dan dapat dipahami oleh orang lain [7]. Di jenjang sekolah menengah pertama, keterampilan menulis terdapat beberapa jenis diantaranya menulis teks iklan, menulis teks eksposisi, menulis puisi, menulis teks eksplanasi, menulis teks persuasif, menulisnteks drama dan yang terakhir menulis teks ulasan [8].

Teks ulasan merupakan salah satu teks yang sering kita jumpai di pembelajaran bahasa Indonesia dan harus dikuasai oleh siswa. Teks ulasan adalah teks yang menyajikan kekurangan dan kelebihan suatu karya [9]. Maksud dari teks ulasan itu sendiri adalah sebuah teks yang menganalisis kelebihan dan kekurangan dari sebuah karya baik novel, buku, film, ataupun karya yang lain.Teks ulasan juga dapat diartikan sebagai teks yang berisi hasil dari penafsiran, pengupasan dan penafsiran terhadap suatu karya seni [10].Teks ulasan bukan hanya sebuah keterampilan yang harus dikuasai, tetapi juga bermanfaat untuk pengembangan diri dalam menyampaikan ide, ikut aktif dalam bersastra dan meningkatkan komunikasi dalam berbahasa [11]. Pembelajaran menulis teks eskposisi pada metode pembelajaran time token arends dapat dikatakan lebih tinggi daripada metode mind mapping di kelas X SMA Negeri 1 Wanasari [12].

Manfaat yang ada dalam teks ulasan ini masih belum dirasakan oleh siswa kelas VIII SMP Katolik St. Louis Cepu. Siswa kelas VIII SMP Katolik St. Louis Cepu masih belum memiliki keterampilan yang baik dalam menulis teks ulasan. Hal ini dapat diketahui dari hasil observasi dan wawancara dengan guru kelas VIII SMP Katolik St. Louis Cepu. Saat diwawancarai, guru menjelaskan bahwa hasil tulisan karya siswa pada jenis teks sebelumnya masih mengacu pada contoh teks yang ada pada buku paket. Seperti kesamaan paragraf pada struktur teks. Kalimat-kalimat yang ada pada contoh teks hanya diubah subyek dan objeknya saja tanpa ada kalimat pengembang yang keluar dari contoh pada jenis teks sebelumnya. Permasalahan yang ada di kelas VIII harus segera dicarikan solusi dalam pembelajaran. Salah satunya adalah pemilihan metode yang sesuai. Pengajar harus memilih metode yang sesuai agar dapat tercapainya tujuan pembelajaran [13]. Salah satu metode yang dapat diimplementasikan dalam pembelajaran menulis teks ulasan adalah dengan menerapkan metode quantum learning.

Metode quantum dapat dikatakan sebagai metode yang mengembangkan minat bakat siswa dalam bentuk pemahaman dan daya ingat siswa. Kelebihan metode quantum learning yaitu dapat membuat suasana belajar mengajar lebih menyenangkan, siswa lebih merasa percaya diri, siswa lebih kreatif, dan dapat meningkatkan komunikasi siswa [14]. Dari kelebihan diatas, penulis memilih metode ini karena nantinya siswa akan menemui suasana kelas yang baru dan terhindar dari rasa bosan saat proses belajar mengajar. Siswa juga nantinya dituntut untuk lebih aktif dan kreatif dalam merespon materi yang telah disampaikan oleh guru.

Metode quantum learning lebih fokus pada proses suatu pembelajaran dengan taraf keberhasilan yang tinggi. Keberhasilan metode ini bukan hanya dipengaruhi oleh faktor internal saja namun faktor lingkungan juga sangat mempengaruhi proses dan hasil belajar siswa [15]. Quantum learning bukan hanya penyampaian materi kepada peserta didik namun juga diajarkan menciptakan emosi yang baik dalam proses belajar mengajar [16]. Metode quantum learning memberikan manfaat yang baik bagi siswa diantaranya siswa bisa lebih aktif, lebih kreatif, lebih komunikatif dan bisa lebih percaya diri. Quantum learning dikatakan bermakna apabila situasi kondisi disekitar pembelajaran sangat mendukung dan penyampaian materi yang tidak monoton [17]. Namun, motode ini dalam penerapannya memerlukan pengalaman dan keterampilan guru, membutuhkan waktu yang lama, serta memerlukan persiapan yang matang. Pembelajaran saat ini memerlukan inovasi dan perubahan mengikuti perkembangan teknologi [18]. Apalagi di masa pandemi seperti ini, siswa melakukan pembelajaran secara daring. Agar metode quantum learning dapat diterapkan dalam masa pandemi ini maka dalam proses belajar mengajar dapat berbantukan dengan berbagai aplikasi. Salah satu aplikasi yang dapat digunakan adalah aplikasi google classroom.

Aplikasi google classroom merupakan solusi bagi dunia pendidikan di masa saat ini. Aplikasi ini dapat membuat proses pembelajaran walaupun tidak tatap muka. Google classroom 
Jurnal SEMANTIKA, Volume 03, No. 01, Agustus 2021, pp. 1-9

merupakan apilkasi yang dapat membuat kegiatan belajar mengajar lebih hemat waktu, teratur dan membuat siswa lebih komunikatif [19]. Guru disini berperan sebagai fasilitator dengan membuka ruang diskusi dan memberikan tugas secara mandiri kepada siswa [20]. Aplikasi google classrom ini merupakan sebuah wadah bagi tenaga pendidik maupun peserta didik dalam pengumpulan dan penilaian tugas dimanapun tanpa terikat jam pelajaran [21]. Keunggulan aplikasi ini yait lebih efektif dan efisien jika digunakan dalam proses pembelajaran [22].

Penerapan metode quantum learning berbantukan aplikasi google classroom diharapkan dapat membuat siswa menulis teks ulasan lebih baik. Penerapan metode dan media ini merupakan solusi untuk pembelajaran di masa pendemi dimana proses pembelajaran dilakukan secara daring. Guru dapat menyampaikan materi dan memberikan penugasan secara daring tanpa perlu adanya kelas. Penerapan metode quantum learning berbantukan aplikasi google classroom dalam pembelajaran keterampilan menulis teks ulasanbelum banyak diteliti. Maka dari itu, penulis ingin melakukan penelitian terkait penggunaan metode quantum learning berbantukan google classroom agar siswa kelas VIII SMP Katolik St. Louis Cepu dapat menulis teks ulasan lebih baik.

\section{METODOLOGI PENELITIAN}

Penelitian ini merupakan penelitian deskriptif kualitatif dengan pendekatan studi kasus. Studi kasus merupakan cara dalam menjelaskan dan menguraikan sebuah fakta dari sebuah kasus secara luas dan lengkap [23]. Tujuan penelitian ini untuk mengetahui keterampilan menulis teks ulasan siswa kelas VIII SMP Katolik St. Louis Cepu terkait dengan orientasi, tafsiran, evaluasi dan rangkuman yang memenuhi indikator. Subjek penelitian ini adalah siswa kelas VIII SMP Katolik St. Louis Cepu yang berjumlah 16 siswa. Dari 16 siswa akan diambil lagi 4 siswa yang memenuhi indikator untuk diwawancarai. Sumber data dalam penelitian ini adalah siswa kelas VIII SMP Katolik St. Louis Cepu. Hasil tes menulis teks ulasan dan hasil wawancara digunakan sebagai data penelitian.

Prosedur pengumpulan data yang digunakan, yaitu Observasi

Observasi merupakan proses pengumpulan data secara langsung di lapangan untuk pemerolehan data untuk menjawab masalah dalam penelitian [24]. Penelitian ini menggunakan teknik observasi terbuka dan langsung. Disini peneliti ikut terjun langsung dalam pembelajaran. Peneliti melakukan proses belajar mengajar dalam pembelajaran menulis teks ulasan. Di sini peneliti bereran sebagai guru.

Tes

Tes merupakan cara untuk mengukur dan menilai kemampuan peserta [25]. Penelitian ini menggunakan metode tes tulis untuk mengukur sejuh mana siswa dapat menulis teks ulasan. Tes tulis dilakukan oleh siswa secara individu setelah guru menerapkan metode quantum learning dalam pembelajaran menulis teks ulasan. Hasil tes kemudian dianalisis untuk mengetahui kesesuaian tulisan siswa dengan indikator. Langkah-langkah dalam pengambilan data dengan metode tes adalah a) Siswa menyiapkan lembar kerja masing-masing dirumah, b) Siswa menulis teks ulasan, c) Siswa mengumpulkan hasil tes menulis dengan cara mengirim gambar foto hasil tes menulis di aplikasi google classroom, d)Hasil tes diterima dan dianalisis oleh peneliti Wawancara

Wawancara adalah proses terjadinya komunikasi antara subjek penelitian dan peneliti [26]. Penelitian ini menggunakan jenis wawancara tidak berstruktur, sebab jenis penelitian ini sesuai dengan pribadi siswa. Adapun langkah-langkah wawancara pada penelitian ini yaitu, a) menyusun pertanyaan tidak tersruktur dengan hanya menyusun garis besar dari pertanyaan yang akan disampaikan, b) wawancara dilakukan dengan siswa secara terbuka, c) wawancara dilakukan pada 4 siswa yang tulisannya telah memenuhi indikator. Pertanyaan di susun berdasarkan hasil menulis teks ulasan siswa, d) hasil wawancara dianalisis sehingga mendapatkan data terkait dengan pembelajaran menulis teks ulasan, e) wawancara dilakukan secara daring.

Dokumentasi 
Dokumentasi adalah teknik pengumpulan data dari sumber tertulis [27]. Dokumentasi adalah penyelidikan terhadap objek dalam bentuk tulisan[28]. Dari pendapat diatas dapat disimpulkan bahwa dokumentasi adalah teknik pengumpulan data yang memiliki sumber berupa tulisan.

Teknik analisis data pada penelitian ini merujuk pada teori Miles dan Huberman dalam Saad yang terdiri dari reduksi data, penyajian data dan penarikan kesimpulan [29]. Teknik triangulasi digunakan untuk validasi data. Triangulasi merupakan cara melihat sesuatu secara realistis dari berbagai sudut pandang sehingga lebih akurat dan dapat dipercaya [30]. Triangulasi yang digunakan adalah triangulasi sumber dengan membandingkan teks ulasan yang telah ditulis siswa dengan hasil wawancara dan juga menggunakan triangulasi metode dimana lebih dari satu metode pengumpulan data yang digunakan pada penelitian ini.

\section{HASIL DAN PEMBAHASAN}

\section{Hasil Penelitian}

Berdasarkan struktur teks ulasan yang dikemukakan oleh Kustina dan Wahdah. Struktur teks ulasan yang ditulis oleh siswa kelas VIII SMP Katolik St. Louis Cepu sudah memenuhi indikator. Berikut teks ulasan yang telah ditulis oleh siswa.

\section{Bentuk Orientasi Teks Ulasan Siswa}

Struktur teks ulasan yang pertama adalah orientasi. Bentuk orientasi yang ditulis siswa kelas VIII SMP Katolik St. Louis Cepu adalah sebagai berikut.

\section{Orientasi}

Cerpen satu ini merupakan karya dari Charissa. E yang bercerita tentang kisah Lily yan kehilangan sahabat kecilnya yang ternyata dibunuh oleh kekasihnya sendiri yaitu Ardan.

\section{Gambar 1. Bentuk Orientasi Teks Ulasan}

Pada hasil menulis teks ulasan, siswa menuliskan bagian orientasi dengan menyebutkan nama pengarang selaku identitas dan juga menjelaskan secara singkat inti dari cerpen tersebut. Cerpen tersebut beisi tentang Lily yang telah kehilangan sahabatnya yang bernama Eri yang telah dibunuh oleh Ardan. Pada bagian orientasi ini, siswa telah mampu membuat struktur teks ulasan sesuai dengan indikator. Peneliti melakukan wawancara dengan siswa mengapa menuliskan orientasi seperti itu, dia menyatakan bahwa bagian orientasi menjelaskan gambaran umum dari cerpen tersebut. Hal ini selaras dengan kutipan hasil wawancara berikut.

Y : : "Apakah saudara sudah paham dengan struktur teks ulasan?"

MTCDC : "Sudah Bu."

Y : "Mengapa saudara membuat orientasi seperti itu?"

MTCDC: "Karena bagian orientasi menjelaskan gambaran umum dari cerpen itu Bu. Jadi saya menuliskan yang pertama pengarang dari cerpen Senandika Bunga Lili dan yang kedua tentang inti dari cerita tersebut."

\section{Bentuk Tafsiran Teks Ulasan Siswa}

Struktur yang kedua adalah tafsiran. Bentuk tafsiran yang ditulis siswa kelas VIII SMP Katolik St. Louis Cepu adalah sebagai berikut. 


\section{b. Tafsiran}

Berawal dari 2 orang siswa siswi SMA bernama Ardan dan Lily, Lily adalah murid baru pindahan dari Jakarta, Pertama kali Ardan melihat Lily Ardan langsung jatuh cinta, pada akhirnya setelah beberapa hari mereka resmi berpacaran, pada saat Lily ke rumah Ardan untuk bertemu orang tua Ardan. Tetapi sembari menunggu makan siang siap Ardan mengajak Lily ke kamarnya yang cukup luas, disitu Lily melihat Ardan bersama perempuan yang bernama Eri, yang bukan lain adalah sahabat lama Lily, yang sudah meninggal yang ternyata di bunuh oleh Ardan, karena Lily kesal terhadap Ardan ia pun membunuh Ardan sebagai balas dendam karena telah membunuh sahabatnya itu, setelah memberi racun ular kepada Ardan Lily pun pulang, sesampainya dirumah ia mendapat bisikan dari sahabatnya Eri, ia pun rindu pada sosok sahabatnya itu, pada akhirnya ia meminum sisa racun yang ia berikan kepada Ardan tadi, pada akhirnya mereka berdua pun meninggal.

\section{Gambar 2. Bentuk Tafsiran Teks Ulasan}

Pada hasil menulis teks ulasan, siswa menuliskan bagian tafsiran dengan menjelaskan cerita dari awal sampai akhir. Pada awal cerita dijelaskan bagaimana pertemuan antara Lily dan Ardan hingga cerita berakhir dengan kematian semua tokoh utama. Pada bagian tafsiran ini, siswa telah mampu membuat teks ulasan sesuai dengan indikator. Peneliti melakukan wawancara terhadap siswa mengapa menuliskan tafsiran seperti itu, dia menyatakan bahwa bagian tafsiran berisi tentang pandangan penulis terhadap cerpen tersebut. Hal ini selaras dengan kutipan hasil wawancara berikut.

Y : : "Apakah saudara sudah memahami secara keseluruhan mengenai struktur teks ulasan?"

DF : "Sudah Bu."

Y : : "Silahkanberi alasan mengapa saudara membuat tafsiran seperti itu?"

DF : : "Karena kemarin saya sudah membaca bahwa tafsiran berisi tentang pandangan saya sebagai penulis terhadap cerpen tersebut. Jadi saya menjelaskan cerpen itu dari awal sampai akhir secara lengkap namun singkat Bu."

\section{Bentuk Evaluasi Teks Ulasan Siswa}

Struktur yang ketiga adalah evaluasi. Bentuk evaluasi yang ditulis siswa kelas VIII SMP Katolik St. Louis Cepu adalah sebagai berikut.

\section{Evaluasi :}

Cerpen yang satu ini menyuguhkan alur cerita yang cukup menarik karena didalamnya menggunakan penggunaan bahasa yang mudah dimengerti banyak orang, dan ada juga penggunaan beberapa bahasa gaul dan kekinian yang menjadikan banyak orang dijaman sekarang lebih mudah untuk memaknainya. Kemudia cerpen yang satu ini pun memiliki tema yang baik karena dapat memberikan gambaran akan isi ceritanya, sehingga kita para pembacanya seolaholah masuk dan hadir dalam jalan cerita yang dialami antara tokoh Ardan dan juga tokoh Lily. Kita juga sebagai para pembacanya ikut merasakan perasaan yang dialami oleh interaksi dan relasi antara kedua tokoh ini, mulai dari perasaan menyenangkan, menghanyutkan, mengangetkan hingga menyedihkan. Cerpen inipun memiliki penceritaan yang sesuai dengan para remaja jaman sekarang.

Kekurangan Cerpen yang satu ini adalah ceritanya tidak cocok dibaca oleh anak-anak dibawah umur sebab isi ceritanya menggambarkan cerita cinta remaja serta beberapa adegan kekerasan dan pemaksaan dalam ceritanya seperti pemaksaan dan kekerasa untuk meminum racun, serta usaha untuk mengakhiri hidup. Tak hanya itu saja, cerpen ini juga kurang memberikan pendidikan moral kepada para pembacanya, karena hanya bertujuan untuk menghibur saja.

Gambar 3. Bentuk Evaluasi Teks Ulasan 
Pada hasil menulis teks ulasan, siswa menuliskan bagian evaluasi dengan menjelaskan keunggulan dan kekurangan dari cerpen tersebut. Cerpen tersebut memiliki keunggulan berupa tema yang bagus, alur yang menarik, dan bahasa yang digunakan mudah dimengerti. Adapun kekurangan dari cerpen tersebut yaitu cerita tersebut kurang cocok dibaca oleh anak dibawah umur dan kurang memberikan pendidikan moral. Pada bagian evaluasi ini, siswa telah mampu membuat struktur evaluasi sesuai dengan indikator. Peneliti melakukan wawancara dengan siswa mengapa menulis evaluasi seperti itu, dia menyatakan bahwa bagian evaluasi berisi tentang penilaian terhadap cerpen tersebut. Hal ini selaras dengan kutipan hasil wawancara berikut.
Y : "Apakah saudara sudah paham tentang struktur teks ulasan?"
DGM : "Sudah Bu."
Y : "Mengapa saudara membuat evaluasi sepertiitu?"
DGM : "Karena sepemahaman saya bagian evaluasi merupakan bagian penilaian dari cerpen itu Bu. Jadi saya menuliskan semua keunggulan dan kekurangan dari cerpen tersebut."

\section{Bentuk Rangkuman Teks Ulasan Siswa}

Struktur yang keempat adalah rangkuman. Bentuk rangkuman yang ditulis siswa kelas VIII SMP Katolik St. Louis Cepu adalah sebagai berikut.

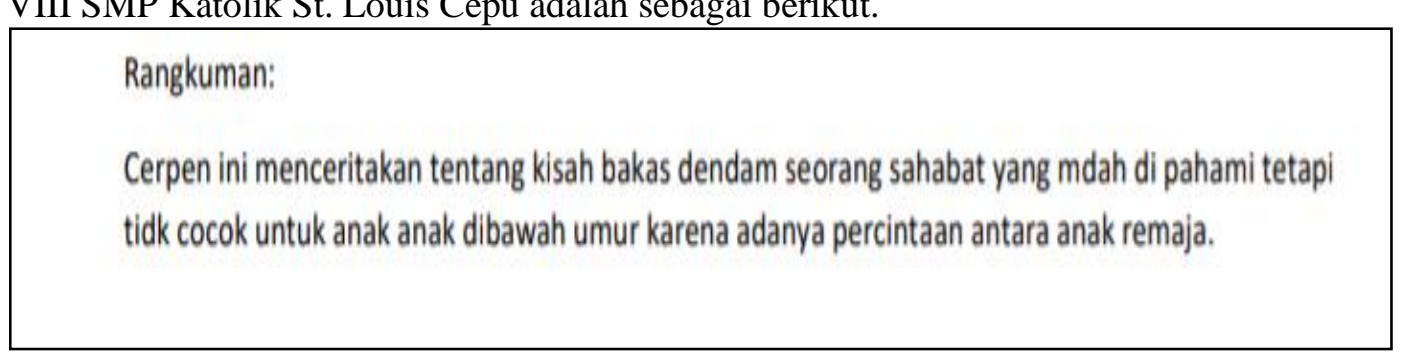

\section{Gambar 4. Bentuk Rangkuman Teks Ulasan}

Pada hasil menulis teks ulasan, siswa menuliskan bagian rangkuman dengan menjelaskan tentang kisah balas dendam seorang sahabat. Cerpen tersebut memiliki keunggulan berupa penggunaan bahasa yang mudah dipahami dan kekurangan dari cerpen tersebut adalah kurang cocok dibaca oleh anak dibawah umur. Pada bagian rangkuman ini, siswa telah mampu membuat struktur rangkuman sesuai dengan indikator. Peneliti melakukan wawancara dengan siswa mengapa menulis rangkuman seperti itu, dia menyatakan bahwa bagian rangkuman berisi tentang kesimpulan dari cerpen tersebut. Hal ini selaras dengan kutipan hasil wawancara berikut.

$\begin{array}{ll}\text { Y } & \text { : "Apakah saudara sudah paham tentang struktur teks ulasan } \\ & \text { terutama bagian rangkuman?" } \\ \mathrm{DF} & : \text { "Sudah Bu." } \\ \mathrm{Y} & : \text { "Mengapa saudara membuat rangkuman sepertiitu? }, \\ \mathrm{DF} & : \text { "Karena bagian rangkuman merupakan kesimpulan secara } \\ & \text { keseluruhan dari suatu karya Bu. Jadi saya membuat rangkuman itu } \\ & \text { menuliskan inti cerita, kelebihan dan kekurangan cerpen tersebut." }\end{array}$

\section{Pembahasan}

Siswa kelas VIII SMP Katolik St. Louis Cepu dalam menuliskan orientasi berisi tentang nama pengarang cerpen tersebut yaitu Charissa E. dan menuliskan gambaran umum dari cerpen tersebut yang berisi tentang balas dendam seorang Lily terhadap Ardan karena telah membunuh sahabat Lily. Orientasi merupakan gambaran umum dari sebuah karya yang akan diulas. Orientasi mencakup nama, kegunaan atau sebagainya yang merupakan gambaran umum dari sebuah karya [31].

Siswa kelas VIII SMP Katolik St. Louis Cepu dalam menuliskan tafsiran berisi tentang pandangan siswa itu tersendiri terhadap cerpen tersebut. Siswa menuliskan tafsiran berawal dari 
Jurnal SEMANTIKA, Volume 03, No. 01, Agustus 2021, pp. 1-9

pertemuan tokoh Lily dan Ardan hingga berakhir dengan kematian mereka berdua. Tafsiran berisi tentang pandangan penulis terhadap karya yang diulas. Tafsiran merupakan sudut pandang penulis terhadap suatu karya [32].

Siswa kelas VIII SMP Katolik St. Louis Cepu dalam menuliskan evaluasi berisi tentang keunggulan dan kekurangan terhadap cerpen tersebut. Keunggulan dari cerpen tersebut adalah tema yang bagus, alur yang menarik, dan bahasa yang digunakan mudah dimengerti. Adapun kekurangan dari cerpen tersebut yaitu cerita tersebut kurang cocok dibaca oleh anak di bawah umur dan kurang memberikan pendidikan moral. Evaluasi berisi tentang penilaian terhadap karya yang diulas. Evaluasi merupakan penjabaran mengenai kelebihan dan kekurangan suatu karya [33].

Siswa kelas VIII SMP Katolik St. Louis Cepu dalam menuliskan rangkuman berisi tentang kesimpulan dari cerpen tersebut. Rangkuman berisi tentang garis besar cerita, keunggulan berupa penggunaan bahasa yang mudah dipahami dan kekurangannya yaitu tidak cocok untuk anak di bawah umur. Rangkuman adalah simpulan secara keseluruhan baik keunggulan maupun kekurangan terhadap sebuah karya [34].

\section{SIMPULAN}

Berdasarkan hasil dan pembahasan dapat disimpulkan bahwa 1) orientasi yang ditulis oleh siswa kelas VIII SMP Katolik St. Louis Cepu dapat dikategorikan baik, siswa menulis bentuk orientasi terkait gambaran umum dari cerpen yang diulas, 2) tafsiran yang ditulis oleh siswa kelas VIII SMP Katolik St. Louis Cepu dapat dikategorikan baik, siswa menulis bentuk tafsiran terkait pandangan penulis terhadap cerpen yang diulas, 3) evaluasi yang ditulis oleh siswa kelas VIII SMP Katolik St. Louis Cepu dapat dikategorikan baik, siswa menulis bentuk evaluasi terkait penilaian terhadap cerpen yang diulas, dan 4) rangkuman yang ditulis oleh siswa kelas VIII SMP Katolik St. Louis Cepu dapat dikategorikan baik, siswa menulis bentuk rangkuman terkait simpulan dari cerpen yang diulas.

\section{REFERENCES}

[1] S. F. Anzar and Mardhatillah, "Analisis kesulitan belajar siswa pada pembelajaran bahasa Indonesia di kelas V SD Negeri 20 Meulaboh Kabupaten Aceh Barat tahun ajaran 2015/2016,"Jurnal Ilmiah Pendidikan Guru Sekolah Dasar, vol. 4, no. 1, pp. 53-64, 2017, [Online]. Available: https://ejournal.stkipbbm.ac.id/index.php/pgsd/article/view/25.

[2] N. Hidayah, "Penanaman nilai-nilai karakter dalam pembelajaran bahasa Indonesia di sekolah dasar," Jurnal Pendidikan dan Pembelajaran Dasar, vol. 2, no. 2, pp. 190-204, 2015 , [Online]. Available: https://doi.org/10.24042/terampil.v2i2.1291.

[3] I. Zulaeha, "Pengembangan model pembelajaran keterampilan berbahasa Indonesia berkonteks multikultural,"Jurnal Penelitian Bahasa, Sastra dan Pengajarannya., vol. 12, no. 1, pp. 97-105, 2013, [Online]. Available:https://doi.org/10.21831/ltr.v12i01.1331.

[4] K. Sholeh and S. Afriani, "Teknik mind mapping sebagai upaya untuk meningkatkan keterampilan menulis cerpen pada siswa sma,"Jurnal Pendidikan Surya Edukasi., vol. 2, no. 2, pp. 26-45, 2016, [Online]. Available:https://doi.org/10.37729/jpse.v2i2.3462.

[5] S. W. Kurniawati, "Pembelajaran menulis teks ulasan dengan SQ3R," Jurnal Bahasa, Sastra dan Pengajarannya, vol. 2, no. 1, pp. 11-18, 2019, [Online]. Available: https://doi.org/10.35194/jd.v2i1.675.

[6] Y. W. Astuti and A. Mustadi, "Pengaruh penggunaan media film animasi terhadap keterampilan menulis karangan narasi siswa kelas V sd,"Jurnal Prima Edukasia., vol. 2, no. 2, pp. 251-262, 2014,[Online]. Available: https://doi.org/10.21831/jpe.v2i2.2723.

[7] Ilham, M. and Wijianti, I. A., Keterampilan Berbicara: Pengantar Keterampilan Berbahasa, 2020, Lembaga Academic \& Reserch Institute, Pasuruan. 
[8] Kosasih, E. (2017). Bahasa Indonesia/ Kementerian Pendidikan dan Kebudayaan, 2017, Kementerian Pendidikan dan Kebudayaan, Jakarta.

[9] A. Nofita, A. Hasani, and A. H. Mawadah, "Hubungan kecerdasan kinestetik dan penguasaan kalimat efektif dengan keterampilan menulis teks ulasan karya siswa kelas VIII SMPN 7 Kota Serang tahun ajaran 2018/2019,"Jurnal Membaca Bahasa \& Sastra.,vol. 4, no. 2, pp. 77-83, 2019,[Online]. Available:http://dx.doi.org/10.30870/jmbsi.v4i2.6311.g4397.

[10] F. Rosyida, Y. Kristiana, and C. Hasanudin, "Analisis keterampilan menceritakan kembali teks ulasan dengan kolaborasi metode fliped classroom dan aplikasi schoology,"Jurnal Linguistik, Sastra, dan Pendidikan.,vol. 5, no. 2, pp. 86-95, 2020, [Online]. Available:https://doi.org/10.51673/jurnalistrendi.v5i2.303.

[11] I. T. Almuharram, Syambastil, and D. Ramdani, "Pembelajaran menulis teks ulasan pada siswa kelas VIII,"Jurnal Pendidikan dan Pembelajaran Khatulistiwa, vol. 8, no. 6, pp. 1-9, 2019, [Online]. Available: https://jurnal.untan.ac.id/index.php/jpdpb/article/view/33435/75676581563.

[12] Ernawati Septi Dwi, Kurniawan Prasetyo Yuli and Ubaedilillah Ubaedillah, "Keefektifan Metode Time Token Arends dan Mind Mapping dalam Menulis Teks Eksposisi", Jurnal Ilmiah Semantika, vol 1 , no. 1, pp. 55-62, [Online]. Available: http://jurnal.umus.ac.id/index.php/semantika/article/view/82.

[13] N. Mayasari, A. K. Amin, and L. Rofiqoh, "Peningkatan pemahaman konsep matematik mahasiswa melalui model pembelajaran active knowledge sharing," Jurnal Math Educator Nusantara., vol. 5, no. 2, pp. 140-152, 2019, [Online]. Available: https://doi.org/10.29407/jmen.v5i2.13513.

[14] U. Qalsum, "Penerapan metode quantum learning dalam upaya meningkatkan hasil belajar belajar siswa kelas VIII.A SMP Pesantren Datok Sulaiman Palopo khususnya pada pembelajaran Bahasa Indonesia,"Jurnal Pendidikan, Bahasa dan Sastra.,vol 4, no. 2, pp. 92 104, [Online]. Available: http://dx.doi.org/10.30605/onoma.4.2.2018.1119.

[15] Z. Arifin, Sudarti, andA. D. Lesmono, "Pengaruh model quantum learning disertai metode eksperimen terhadap hasil belajar fisika siswa di SMA Negeri Kalisat,"Jurnal Pembelajaran Fisika., vol. 4, no. 4, pp. 365-370, 2016, [Online]. Available:https://jurnal.unej.ac.id/index.php/JPF/article/view/3091/2489.

[16] A. M. Ramlan, "Peningkatan hasil belajar mahasiswa melalui metode quantum learning dengan teknik mind mapping," Jurnal of Educational Science and Technology., vol. 3, no. 2, pp. 129-135, 2017,[Online]. Available:https://doi.org/10.26858/est.v3i2.3551.

[17] R. N. Hidayah, A. Darmuki, andC. Hasanudin, "Peningkatan keterampilan menulis puisi dengan menggunakan metode quantum learning dan media video pada siswa kelas X IPA I SMA Negeri 2 Blora tahun ajaran 2018/2019,"Jurnal Linguistik, Sastra, dan Pendidikan., vol. 4, no. 1, pp. 309-320, 2019, [Online]. Available:http://ejournal.unwmataram.ac.id/trendi/article/view/152/123.

[18] A. K. Amin, "Kajian konseptual model pembelajaran blanded learning berbasis web untuk meningkatkan hasil belajar dan motivasi belajar," Jurnal Pendidikan Edutama., vol. 4, no. 2, pp. 51-63, 2017, [Online]. Available:https://ejurnal.ikippgribojonegoro.ac.id/index.php/JPE/article/view/55.

[19] N. Asnawi, "Pengukuran usability google classroom sebagai e-learning menggunakan USE Questionnaire (studi kasus: Prodi Sistem Informasi UNIPMA),"Jurnal of Computer, informasi system, \& technology management., vol. 1, no. 2, pp. 17-21, 2018,[Online]. Available:http://doi.org/10.25273/research.v1i1.2451.

[20] I. Savitri, "Penggunaan pembelajaran 4.0 berbantuan aplikasi google classroom dan google form dalam mata kuliah ilmu sosial budaya dasar,"Jurnal Borneo Saintek., vol. 2, no. 1, pp. 20-25, 2019,[Online]. Available: https://doi.org/10.35334/borneo_saintek.v2i1.632.

[21] N. R. Ashadiand S. Suhaeb, "Hubungan pemanfaatan google classroom dan kemandirian terhadap hasil belajar mahasiswa PTIK pada masa pandemi,"Jurnal Media Elektrik., vol. 17, no. 2, pp. 46-51, 2020, [Online]. Available:http://103.76.50.195/mediaelektrik/article/view/14036/8239. 
[22] L. U. AliandM. Zaini, "Pemanfaatan program aplikasi google classroom sebagai upaya meningkatkan motivasi dan prestasi belajar mahasiswa pada perkuliahan dasar-dasar pendidikan,"Jurnal Society Jurusan Tadris IPS., vol. 11, no. 1, pp. 27-34, 2020, [Online]. Available:https://doi.org/10.20414/society.v11i1.2297.

[23] R. R. Lubis, Haidir, and B.E. Rusadi, "Problematika implementasi scientific approach dalam pembelajaran Fikih (studi kasus di MTs. PAI Medan)," Jurnal Agama dan Pendidikan Islam., vol. 11, no. 1, pp. 118-134, 2019, [Online]. Available:https://doi.org/10.30596/intiqad.v11i1.3141.

[24] H. Novitasari, Sutrimah., and C. Hasanudin, "Analisis keterampilan menulis teks drama dengan pembelajaran quantum," Jurnal Ilmu Pendidikan Nonformal AKSARA., vol. 6, no. 2, pp. 179-190, 2020, [Online]. Available:http://dx.doi.org/10.37905/aksara.6.2.179190.2020 .

[25] N. Hidayah and Novita,"Peningkatan kemampuan membaca permulaan dengan menggunakan metode struktur analitik sintetik (SAS) mata pelajaran Bahasa Indonesia pada peserta didik kelas II C semester II di MIN 6 Bandar Lampung T.A 2015/2016,"Jurnal Pendidikan dan Pembelajaran., vol. 3, no. 1, pp. 85-102, 2016, [Online]. Available:https://doi.org/10.24042/terampil.v3i1.1331.

[26] M. D. Umam, "Analisis kesalahan siswa dalam menyelesaikan soal cerita Matematika materi operasi hitung pecahan,"Jurnal MATHEdunesia., vol. 3, no. 3, pp. 131-134, 2014, [Online]. Available: https://jurnalmahasiswa.unesa.ac.id/index.php/mathedunesa/article/view/12779.

[27] M. Pritandhari, "Penerapan komik strip sebagai media pembelajaran mata kuliah Manajemen Keuangan mahasiswa Universitas Muhammadiyah Metro,"Jurnal Program Studi Pendidikan Ekonomi., vol. 4, no. 2, pp. 1-7, 2016, [Online]. Available: http://dx.doi.org/10.24127/ja.v4i2.631.

[28] R. S. Waskitoningtyas, "Analisis kesulitan belajar Matematika siswa kelas V Sekolah Dasar Kota Balikpapan pada materi satuan waktu tahun ajaran 2015/2016,"Jurnal Ilmiah Pendidikan Matematika., vol. 5, no. 1, pp. 24-32, 2016, [Online]. Available: http://doi.org/10.25273/jipm.v5i1.852.

[29] Saad, S., Hak Pemeliharaan dan Penangkapan Ikan, 2009, LKiS Yogyakarta, Yogyakarta.

[30] Suparno, P., Riset Tindakan Untuk Pendidik, 2007, PT Grasido, Jakarta.

[31] M. A. Kastiyawan, Y. Hudiyono, and M. R. Ahmad, "Pengembangan media Levidio Storyboard dalam pembelajaran menulis teks ulasan film/drama pada siswa kelas XI Smk," Journal of Culture, Arts, Literature, and Linguistic., vol. 3, no. 1, pp. 15-30, 2017, [Online]. Available: http://dx.doi.org/10.30872/calls.v3i1.774.

[32] R. Kustina and Z. Wahdah, "Pengaruh penerapan model pembelajaran kooperatif tipe team game tournament (TGT) terhadap kemampuan membedakan struktur teks ulasan dengan teks biografi siswa kelas VIII-3 SMP Negeri 17 Banda Aceh," Jurnal Metamorfosa., vol. 4, no. 1 p. 93-103, 2016, [Online]. Available: https://ejournal.bbg.ac.id/metamorfosa/article/view/147.

[33] I. Suryadi, Suhartono, and P. Utomo, "Pelaksanaan pembelajarn menulis teks ulasan siswa kelas VIII SMP Negeri 17 Kota Bengkulu," Jurnal Ilmiah KORPUS., vol. 4, no. 2, pp. 185194, 2020, [Online]. Available: https://doi.org/10.33369/jik.v4i2.8334.

[34] K. A. W. Aswin, "Pengaruh metode cooperative integrated reading and composition (CIRC) terhadap hasil belajar menulis teks ulasan kelas VIII MTS Al-Musthofa tahun ajaran 2017/2018," Jurnal Bapala., vol. 5, no. 2, pp. 1-11, 2018, [Online]. Available: https://jurnalmahasiswa.unesa.ac.id/index.php/bapala/article/view/25689. 